\title{
Sedimentary and geochemical characteristics of the Triassic Chang 7 Member shale in the Southeastern Ordos Basin, Central China
}

\author{
Jing-Wei Cui ${ }^{1,2} \cdot$ Ru-Kai Zhu' ${ }^{1}$ Zhong Luo ${ }^{1} \cdot$ Sen $\mathrm{Li}^{1}$
}

Received: 29 November 2017 / Published online: 26 March 2019

(c) The Author(s) 2019

\begin{abstract}
The Ordos Basin is the largest petroliferous basin in China, where the Chang 7 Member shale serves as the major source rock in the basin, with an area of more than $100,000 \mathrm{~km}^{2}$. So far, sedimentary and geochemical characterizations have rarely been conducted on the shale in shallow $(<1000 \mathrm{~m})$ areas in the southeastern part of the basin, but such characterizations can help identify the genesis of organic-rich shale and promote the prediction and recovery of shale oil. In this paper, several outcrop sections of the Chang 7 Member in the Tongchuan area were observed and sampled, and sedimentary and geochemical characterizations were conducted for the well-outcropped YSC section. The study results show that the Chang 7 Member shale is widely distributed laterally with variable thickness. The organic-rich shale is $7-25 \mathrm{~m}$ thick in total and exhibits obvious horizontal variation in mineral composition. In the eastern sections, the shale contains organic matter of Type $\mathrm{II}_{2}-\mathrm{III}$ and is low in thermal maturity, with high clay mineral content, low K-feldspar content, and no pyrite. In the western sections, the shale contains Type $\mathrm{II}_{1}$ organic matter and is low in thermal maturity, with high clay mineral, $\mathrm{K}$-feldspar, and pyrite contents. The YSC section reveals three obvious intervals in vertical mineral composition and organic abundance. The Chang 7 Member organic-rich shale (TOC $>10 \%$ ) contains mainly sapropelite and liptinite, with Type II kerogen. It is generally characterized by a hydrocarbon potential of more than $70 \mathrm{mg} / \mathrm{g}$, low maturity, and shallow-semideep lacustrine facies. In the western sections, the shale, still in a low maturity stage, has a higher hydrocarbon potential and is optional for shale oil recovery. However, the Chang 7 Member shale in the study area is highly heterogeneous and its shale oil recovery is practical only in the organic-rich intervals.
\end{abstract}

Keywords Ordos Basin $\cdot$ Chang 7 Member oil $\cdot$ Organic-rich shale $\cdot$ Sedimentary characteristics $\cdot$ Geochemical characteristics

\section{Introduction}

The Ordos Basin is the largest petroleum production basin in China, where the PetroChina Changqing Oilfield Company has produced more than 50 million tonnes of oil and gas each year for the past four consecutive years. The Mesozoic

Edited by Jie Hao

Jing-Wei Cui

jingwei.cui@126.com

1 Research Institute of Petroleum Exploration and Development, PetroChina, Beijing 100083, China

2 Shandong Provincial Key Laboratory of Depositional Mineralization and Sedimentary Minerals, Shandong University of Science and Technology, Qingdao 266590, Shandong, China
Triassic Chang 7 Member shale serves as the major source rock in the basin (Zhang and Li 2001; Yang et al. 2016). It is distributed extensively and has a high expulsion efficiency and supplies oil for a number of tight play zones (e.g., Chang $4+5$, Chang 6 , Chang 8 , and Chang 9). The recently estimated oil resources exceed 12.8 billion tonnes (Zhang et al. 2006; Deng et al. 2009). Driven by the shale gas revolution in North America, the Chang 7 Member organic-rich shale is coming into the spotlight for exploration for, and research into, tight and shale oils (Miller et al. 2008; Jarvie 2012; Clarkson et al. 2012; Donovan et al. 2012; Yang et al. 2013; Zou et al. 2013; Zhang et al. 2015). Currently, the Chang 7 Member unconventional oil is mainly recovered by horizontal well volume fracturing techniques. The Xin'anbian oilfield, the first large tight oil reservoir in China, was discovered in the central part of the basin. 
Previous studies of Chang 7 Member unconventional petroleum often focused on the genesis and structure of lacustrine gravity flow sandstone, the formation mechanism of the organic-rich shale, subtle reservoir evaluation, accumulation mechanisms of oil, evaluation of mobile oil, and identification of sweet spots (Zou et al. 2010; Zhang et al. 2009, 2010; Cui et al. 2016; Yang et al. 2015). In a State Key Program for Basic Research of China (937 Program) project, we reviewed the literature on unconventional petroleum geology in China and abroad, and found that fine-grained sediments were deemed as a key object (Schieber et al. 2007; Zou et al. 2013; Lazar et al. 2015). Unfortunately, there are only few continuous shale cores and little data on meter-scale macroscopic variations. Outcrops are the most practical choice for studying fine-grained sediments. For the southeastern Ordos Basin, especially the Tongchuan area, a lot of studies have been conducted on shale with respect to sedimentary environment, genesis, distribution, characteristics, and resources (Lu et al. 2006; Zhang et al. 2006; Li et al. 2009; Ren 2008), but no detailed sedimentary and geochemical characterizations have been made of outcrops. The horizontal and vertical sedimentary and geochemical characterizations of organic-rich shale in Chang 7 Member are insufficiently detailed. This has made it difficult to get a better understanding on the formation mechanisms and sedimentary patterns of fine-grained sediments and to select intervals for shale oil production. Even worse, the decline of global oil prices and limited knowledge of shale geology have forced many shale oil production plants to shut down.

In this paper, several outcrop sections of Chang $7 \mathrm{Mem}$ ber in the Tongchuan area were observed and sampled. Based on available logs and drilling data, the sedimentary and geochemical characterizations were conducted for the well-outcropped YSC section to describe the longitudinal variation of organic-rich shale. Finally, the sedimentary pattern of the Chang 7 Member shale was established.

\section{Geological setting and experiments}

\subsection{Geological setting}

The Ordos Basin is a typical superimposed basin in central China. It was in a marine environment before the Early Permian. Along with the water regression toward the east, south, and west after the Early Permian, it evolved into a marine-continental cratonic basin in the Paleozoic and then into a continental lacustrine basin in the Mesozoic. In the basin, there are three petroliferous systems (from bottom to top): the Lower Paleozoic Ordovician marine gas-bearing assemblage, the Upper Paleozoic Carboniferous-Permian transitional gas-bearing assemblage, and the Mesozoic Triassic continental oil-bearing assemblage. The basin, as a whole, has a large west-trending gentle slope with a gradient of about $1^{\circ}$ (Fig. 1a, b). Depending on the basement and fault characteristics, the basin is divided into six secondorder tectonic units, including the Weibei Uplift, Yishan (Shanbei) Slope, Tianhuan Depression, Yimeng Uplift, Xiyuan Thrust, and Jinxi Flexural Fold. The Weibei Uplift, trending NS-SW, is located in the southeastern part of the basin. Bordered by the Weihe Graben and Yuxi Uplift to the south, the Weibei Uplift is higher in the south than in the north and connects with the southern margin of the Jinxi Flexural Fold to the east to form a cascade fold at the southeastern margin of the basin.

In the southeastern Ordos Basin, the Quaternary overburden is dominant. Outcrops are found in the Triassic Yanchang Formation in valleys and hillsides, which lies disconformably with the Zhifang Formation with varying denudation at the top and in parallel unconformity with the Jurassic Yan' an or Fuxian Formation at the bottom. Overall, the Yanchang Formation developed in a period when the lacustrine basin was quite large. This formation contains ten oil formation (Chang 1-10) members from top to bottom (Fig. 1c). The Chang 7 Member represents the period that the lacustrine basin suffered the maximum flooding, when a semideep-deep lacustrine sedimentary system was deposited in the southern part of the Ordos Basin (Yang et al. 2010). A black shale sequence at the bottom of Chang 7 Member, also known as "Zhangjiatan shale," is a regional marker bed. In the previous studies, the oil shale in the Yanchang Formation was believed to be controlled by sedimentary facies. In the Wuqing-Qingyang area at the center of the lacustrine basin, the deep lacustrine oil shale is generally $20-30 \mathrm{~m}$ thick, and even up to $40 \mathrm{~m}$. In the northern Shaanxi area, the shallow lacustrine oil shale in the eastern part is generally less than $10 \mathrm{~m}$ thick, and the semideep-deep lacustrine oil shale in the southeastern part is generally $10-20 \mathrm{~m}$ thick. The Chang 7 Member oil shale in this part of the basin is characterized by wide distribution, miscellaneous occurrences, rich foliation, high asphaltene content, high resource potential, and high geochemical grade. The Chang 7 Member oil shale outcrops in the Yijunnan-Tongchuan-Xunyi area in the southern part of the basin. Typical outcrop sections include the Zaoyuan (ZY), Niejiahe (NJ), Beiyingou (BY), Yishicun (YSC), Jiaquhe (JQH), Qianlieqiao (QLQ), Liushutai (LST), Hejiafang (HJF), Bawangzhuang (BWZ), Tangnihe (TN), Maquan (MQ), and Mazhuangcun (MZ), as shown in Fig. 1d.

\subsection{Experiments}

Samples were taken from eight outcrop sections, i.e., ZY, NJ, BY, YSC, BWZ, TN, MQ, and MZ, as shown in Fig. 1d. The shale samples were analyzed for properties and minerals. The geochemical characteristics of 294 samples over a thickness of $40 \mathrm{~m}$ in the YSC section were obtained. 

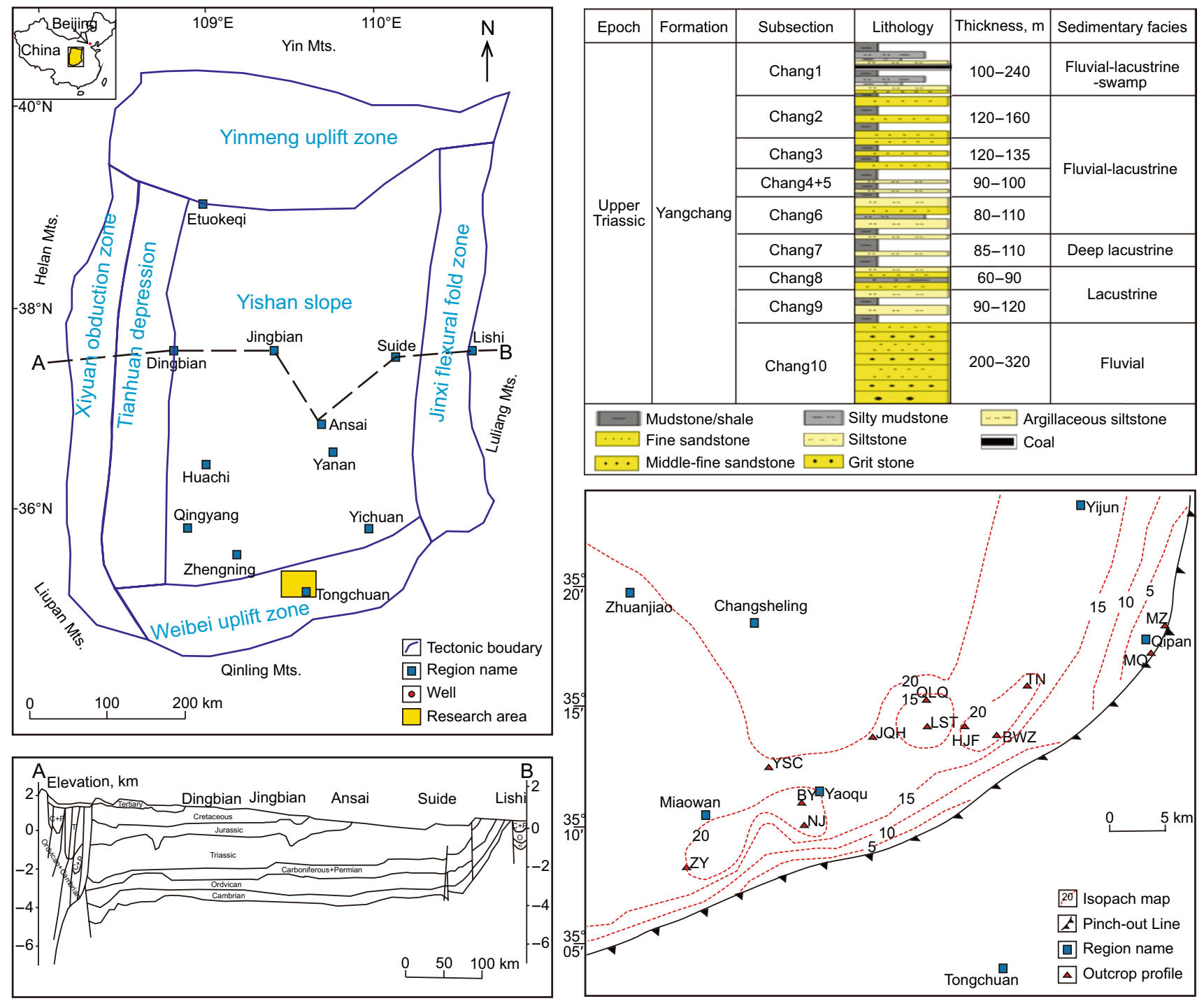

Fig. 1 Tectonic unit, EW stratum profile, and lithology of Ordos basin and outcorp profiles and oil shale thickness in the research area (a) (top left): Tectonic zoning of the Ordos Basin and location of the research area; (b) (bottom left): EW stratum profile of the basin (modified from Yang et al., 2005); (c) (top right): lithology and pay zone division of the Triassic Yanchang Formation; (d) (bottom right): typical outcrop profile and oil shale thickness in the study area (modified from Li et al., 2014)

Total organic carbon (TOC) and total sulfur (TS) were determined with a Leco CS230 carbon-sulfur detector according to GB/T 19145-2003. First, about $10 \mathrm{mg}$ of powdered sample was weighed on an electronic balance and then placed into a porous porcelain crucible that had been heated in a $1000{ }^{\circ} \mathrm{C}$ Digital Muffle Furnace for $2 \mathrm{~h}$. Second, a sufficient volume of $12.5 \% \mathrm{HCl}$ was added to the crucible and heated on a hot plate for $2 \mathrm{~h}$ until it was fully reacted with sample. Third, the sample was washed with distilled water in crucible once every $30 \mathrm{~min}$ for 3 days. Finally, crucible and sample were dried in a $60{ }^{\circ} \mathrm{C}$ oven, and cooled before TOC and TS analysis.
Rock-Eval pyrolysis was conducted at the Key Laboratory of Petroleum Geochemistry, CNPC, following the procedure recommended in GB/T 18602-2012. In the experiment, $30-50 \mathrm{mg}$ of powdered sample was weighed on an electronic balance and put into the Rock-Eval 6 crucible for pyrolysis. The measurement parameters included free hydrocarbon ( $S_{1} \mathrm{mg} \mathrm{HC/g}$ rock), hydrocarbon potential ( $\mathrm{S}_{2}$ $\mathrm{mg} \mathrm{HC/g}$ rock), maturity, and maximum pyrolysis temperature $\left(T_{\max },{ }^{\circ} \mathrm{C}\right)$. Source rock parameters included hydrogen index (HI), oxygen index (OI), and productivity index (PI).

Whole-rock mineral and clay mineral compositions of the shales were analyzed by using a Rigaku TTR X-ray diffractometer under the conditions recommended in SY/T 
5163-2010. During the whole-rock mineral composition analysis, 300-mesh powdered samples were selected to calculate the mass ratios of the minerals using the analysis software and the $K$ value given in the international standard. The clay mineral composition was obtained by five steps. First, the samples were suspended to extract clay minerals. Second, the clay extracts were naturally dried at normal temperature and tested. Third, the sections were saturated with ethylene glycol at $60{ }^{\circ} \mathrm{C}$ for $8 \mathrm{~h}$ and tested again. Fourth, the sections were taken out of the diffractometer and heated at $550{ }^{\circ} \mathrm{C}$ for $2.5 \mathrm{~h}$. Finally, the contents of clay minerals were calculated by using analysis software.

\section{Results and discussion}

\subsection{Horizontal sedimentary and geochemical characteristics}

The Tongchuan area is located in the Weibei Uplift and is a NW-dipping landform. The geological map of Binxian county (I4907, 1: 200000) shows that the oil shale intervals to the south of the oil shale outcrop line are denuded and the area to the northwest contains oil shale. According to the measurement of dip angles, among the eight outcrop sections, the ZY, BY, YSC, NJ, and MQ sections have a fairly flat or even horizontal attitude; the BWZ section shows a NNW inclination of $8^{\circ}-10^{\circ}$ and the MQ section shows a NNW inclination of $5^{\circ}-8^{\circ}$; the TN section, near a fault belt, is much steeper, with an NNE inclination of more than $40^{\circ}$, and up to $70^{\circ}$ in oil shale intervals. Previous studies detected some liberal small-sized folds and minor fault structures locally in the southeastern part of the Ordos Basin, where the burial depth of oil shale generally increases from the southeast to the northwest; however, constrained by local landforms, the maximum valley-hillside height difference can be more than $200 \mathrm{~m}$ (Ren 2008; Li et al. 2014).

Field observations of eight sections suggest that the shale layers are highly heterogeneous and exhibit three sedimentary phenomena: (a) the presence of thin-layered tuffs in shale intervals (Fig. 2c, e, 1, k); (b) the presence of lenses or nodules (Fig. 2, d, j); and (c) the presence of sand (Fig. 2f, $\mathrm{g}, \mathrm{m}, \mathrm{p})$.

The whole-rock mineral composition analysis reveals that the samples from eight outcrop sections differ greatly in mineral composition (Fig. 3). In the western sections (TN, $\mathrm{NJ}, \mathrm{BY}, \mathrm{ZY}$, and BWZ), the shale samples contain quartz (22\%-37\%), K-feldspar (>4\%), clay minerals $(28 \%-45 \%)$, and pyrite ( $>4 \%)$. In the eastern sections (MZ, and MQ), the shale samples contain quartz (26\%-37\%), K-feldspar $(<4 \%)$, and clay minerals $(52 \%-60 \%)$. Clearly, the shale samples from the western sections have lower clay content and higher pyrite and K-feldspar contents than those from the eastern sections. Such differences in mineral composition may imply different sedimentary provenances and environments. Jarosite, a weathering product of pyrite, is a weathering indicator, and its relative content can be used to evaluate the magnitude of weathering. All the samples, except those from J6 and BY2, have a jarosite content of less than 5\%. Fresh samples used in this study were collected by digging trenches to minimize potential influence of weathering on outcrop samples.

The geochemical characterization shows that shale samples are very different in geochemical parameters. The samples from the western sections (TN, NJ, BY, ZY, and BWZ) have TOC of more than $10 \%$ and TS of higher than $2.7 \%$, whereas the samples from the eastern sections (MZ and MQ) have TOC of less than $5 \%$ generally or up to $7.2 \%$ individually and TS of less than $0.1 \%$, as shown in Fig. 4a. Ren (2008) suggested TS of 3\% or higher after evaluating minerals of oil shale from the western sections of Tongchuan, confirming reliability of our test result. The Rock-Eval pyrolysis indicates that the samples from the western sections have a higher hydrocarbon potential $\left(\mathrm{S}_{1}+\mathrm{S}_{2}\right)$ of more than $80 \mathrm{mg} / \mathrm{g}$ and an average $S_{1}$ of $4.15 \mathrm{mg} / \mathrm{g}$, whereas the samples from the eastern sections have a lower hydrocarbon potential $\left(S_{1}+S_{2}\right)$ of less than $15 \mathrm{mg} / \mathrm{g}$ and an average free hydrocarbon content of $0.09 \mathrm{mg} / \mathrm{g}$, as shown in Fig. $4 \mathrm{~b}$.

According to HI-OI and HI-T $\mathrm{T}_{\max }$, the shale samples from the western sections contain Type $\mathrm{II}_{1}$ organic matter, while the shale samples from the eastern sections contain Type $\mathrm{II}_{2}-\mathrm{III}$ organic matter, as shown in Fig. 5. The vitrinite reflectance $\left(R_{\mathrm{o}}\right)$ is $0.6 \%-0.8 \%$ for the samples from the western sections (TN, NJ, BY, and ZY) and $0.5 \%-0.6 \%$ for the samples from the eastern sections (MZ, and MQ), whereas the $R_{\mathrm{o}}$ of the samples from BWZ is close to that of the samples from the eastern sections, as shown in Fig. 6 . Generally, the samples from the eastern sections have lower TOC, inferior organic matter, and lower maturity than those from the western sections. It can be seen that the shale in the eastern sections is essentially immature, implying no shale oil is available for production. Although previous studies have shown that shale in the Tongchuan area thickens from west to east and from south to north, based on the horizontal outcrop variation of oil shale locally, the great thickness does not correspond to better source rock quality. Li et al. (2014) graded the oil shale in the Tongchuan area by oil content using $\Delta \log R$ method (which is used to identify and calculate the organic carbon with logging data), together with the drilling data. This study proposes that the eastern sections represent low-quality resource areas, while the western sections represent medium-quality resource areas. 


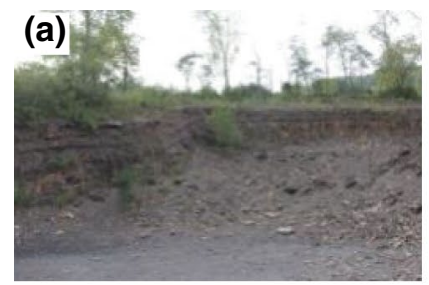

ZY profile, stratum nearly horizontal

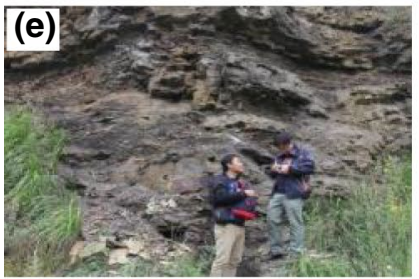

BY profile, stratum nearly horizontal

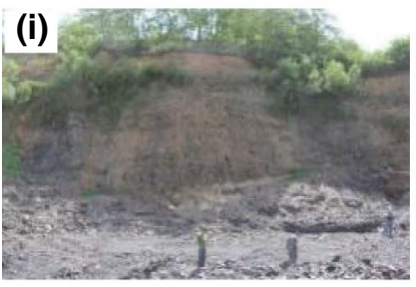

BWZ profile, The forward bedding

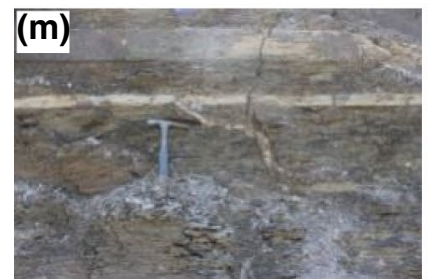

MZ profile, black shale with thin sand shee and sandstone veins

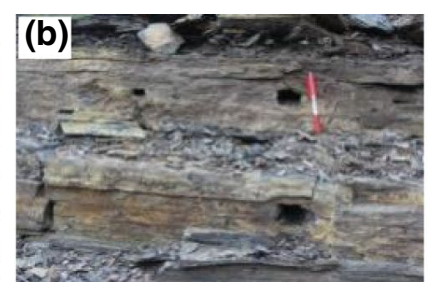

ZY profile, Holes may the result of fish poop fossile fall off

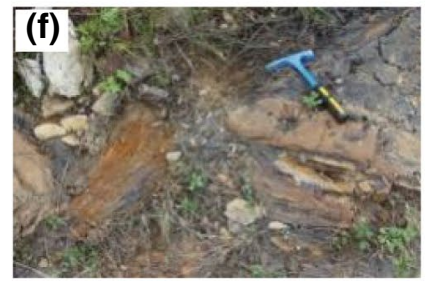

BY profile, Cross sandstone veins (or tuff) in the shale

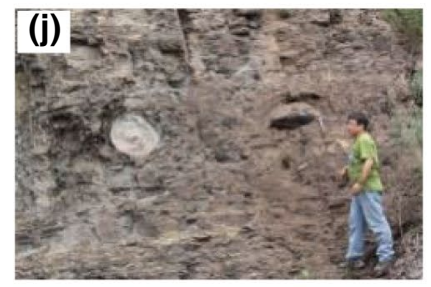

BWZ profile, Carbonate concretions in shale

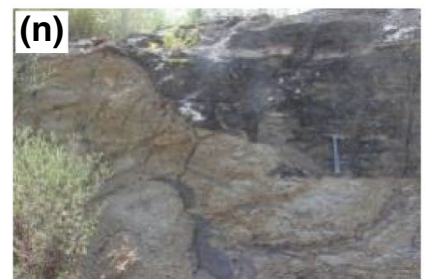

MZ profile, Black shale with thin sand sheet, and the underlying of sandstone

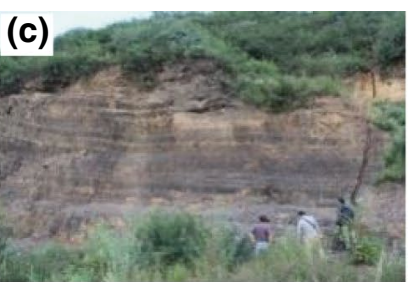

NJ profile, black shale with thin tuff layers

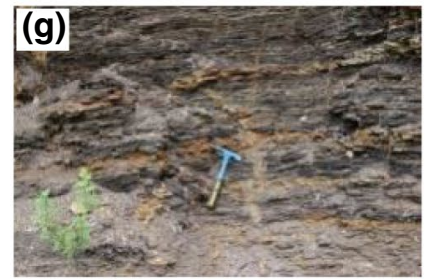

YSC profile, liquefied vein oblique to the shale bedding

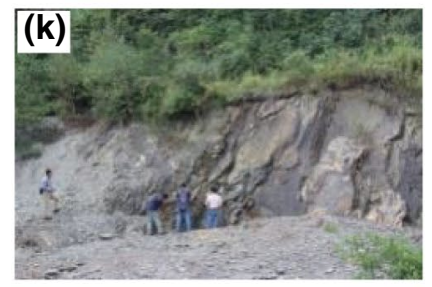

TN profile, stratigraphic dip nearly $70^{\circ}$, developed fault red tuff

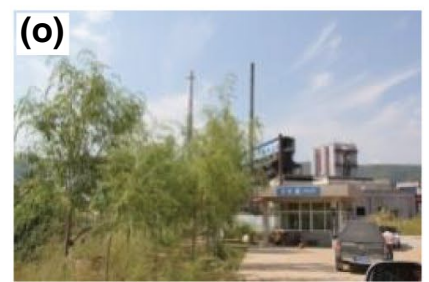

MZ profile, the oil shale processing company has been stalled

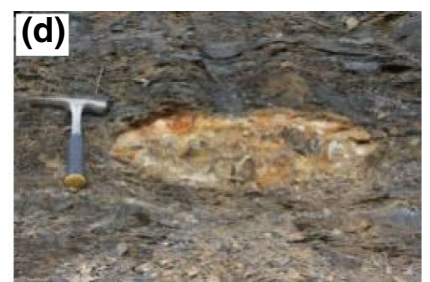

NJ profile, black shale with tuff lens

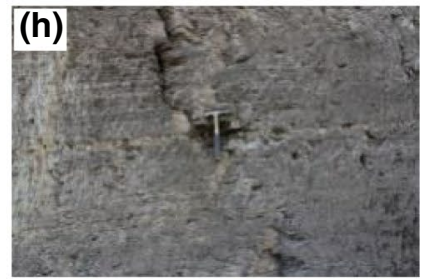

YSC profile, Thin tuff layers in the shale

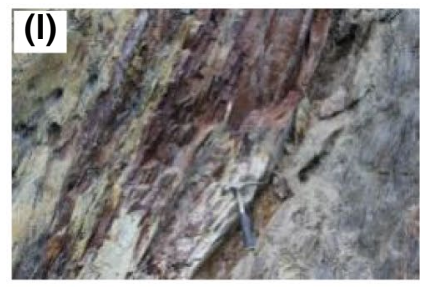

TN profile, Development of fault red tuff

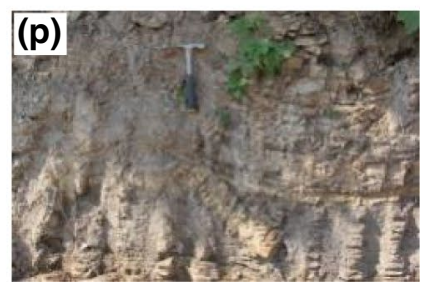

$\mathrm{MQ}$ profile, black shalewith thin layer-middle sandstone, sandstone veins

Fig. 2 Photos and typical sedimentary phenomena of the eight outcorp profiles in Southeastern Ordos basin. The profile name is Zaoyuan (ZY), Niejiahe (NJ), Beiyingou (BY), Yishicun (YCS), Bawangzhuang (BWZ), Tangnihe (TN), Maquan (MQ), and Mazhuangcun (MZ) profiles. Abbreviation name is listed within brackets

\subsection{Vertical sedimentary and geochemical characteristics}

The shale intervals observed from the outcrop sections show strong heterogeneity. Typically, the samples from the YSC section (Fig. 1) were selected for analyzing the vertical sedimentary and geochemical characteristics of shale. As the Chang 7 Member high-quality source rocks are rich in thin-layered tuffs, 156 layers of tuffs were sampled from the YSC section at a centimeter-scale. Zhang et al. (2009) identified more than 180 layers of tuffs at millimeter- to centimeter-scale in the Chang 7 Member source rocks from
Well Zheng- 8 in the southern part of the Ordos Basin and concluded after observation and calculation that the tuffs gradually thin from the southwest to the northeast (with a thickness of more than $1.0 \mathrm{~m}$ in the Zhengning-Huangling area) and the tuffs are either airborne or waterborne (Deng et al. 2008; Zhang et al. 2009). Most scholars believed that the volcanic crater was derived from the Qingling orogeny (Deng et al. 2008; Wang et al. 2014).

The mineral composition analysis shows that there are two types of lithologies across the YSC section: the Chang 8 Member sandstone in the lower part and the Chang 7 Member shale in the upper part (Fig. 7). The former is 


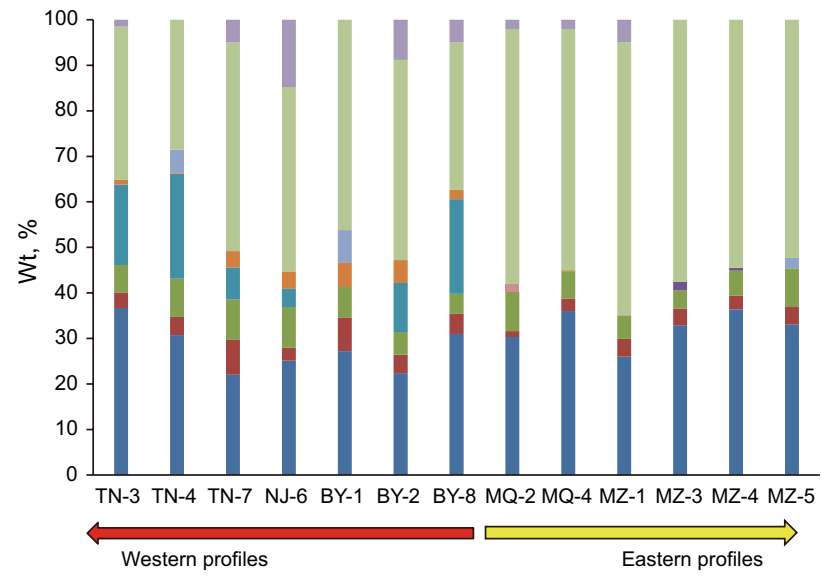

Fig. 3 Mineral composition of shale collected in western and eastern profiles. Capital letter in $\mathrm{x}$-coordinate is the abbreviation of profile name, and the munber is the samples number. eg. Niejiahe (NJ), Beiyingou (BY), Tangnihe (TN), Maquan (MQ), and Mazhuangcun (MZ) profiles

prominently marked by the presence of chlorite $(\mathrm{C} \%)$, and it is a typical product in an alkaline environment (Sruoga et al. 2004; Huang et al. 2009). The latter can be subdivided into three sub-members, i.e., F1, F2, and F3, from bottom to top (Fig. 7). F1 has high quartz, clay mineral, but low plagioclase content. F2 has low quartz content, alternating low-high-low clay mineral, and slightly high K-feldspar content. F3 has alternating low-high-low quartz, K-feldspar, and kaolinite contents.

Obviously, the whole-rock mineral and clay mineral compositions are affected by deposition and diagenesis (Sonnenberg et al. 2011; Sruoga et al. 2004; Huang et al. 2009). In this study, the Chang 7 Member shale was investigated for vertical variation of the whole-rock and clay mineral compositions. It is found that the three sub-members (with a total thickness of $28 \mathrm{~m}$ ) vary in an ascending order of whole-rock and clay mineral compositions vertically. When F1 (8 m) was deposited, the water began to deepen, and the shale was interrupted by thick tuffs $(>2 \mathrm{~cm})$ and contained a quite high content of feldspar, followed by kaolinite; at the end of this deposition period, thick siltstone bodies (gravity flow) were developed. When F2 (13 m) was deposited, the water deepened further and tuffs with different thicknesses were deposited; the shale in this period contained a fairly low and stable content of quartz, and an alternating low-high-low content of feldspar, clay minerals. When F3 (7 m) was deposited, several layers of thin tuffs $(<2 \mathrm{~cm})$ were developed, and the shale contained a relatively high content of quartz and an alternating low-high-low content of clay minerals.

The geochemical characterization results reveal that the 294 shale samples from the YSC section reflect three TOC intervals with respect to free hydrocarbon $\left(\mathrm{S}_{1}\right)$, pyrolysis hydrocarbon $\left(\mathrm{S}_{2}\right)$, hydrocarbon potential $\left(\mathrm{S}_{1}+\mathrm{S}_{2}\right)$, hydrogen index $(\mathrm{HI})$, and organic type parameter $\left(\mathrm{S}_{2} / \mathrm{S}_{3}\right)$. The three
Fig. 4 Source rock parameters of shale collected in western and eastern profiles. Capital letter in $\mathrm{x}$-coordinate is the abbreviation of profile name, and the munber is the samples number. eg. Zaoyuan (ZY), Niejiahe (NJ), Beiyingou (BY), Yishicun (YCS), Bawangzhuang (BWZ), Tangnihe (TN), Maquan (MQ), and Mazhuangcun (MZ) profiles
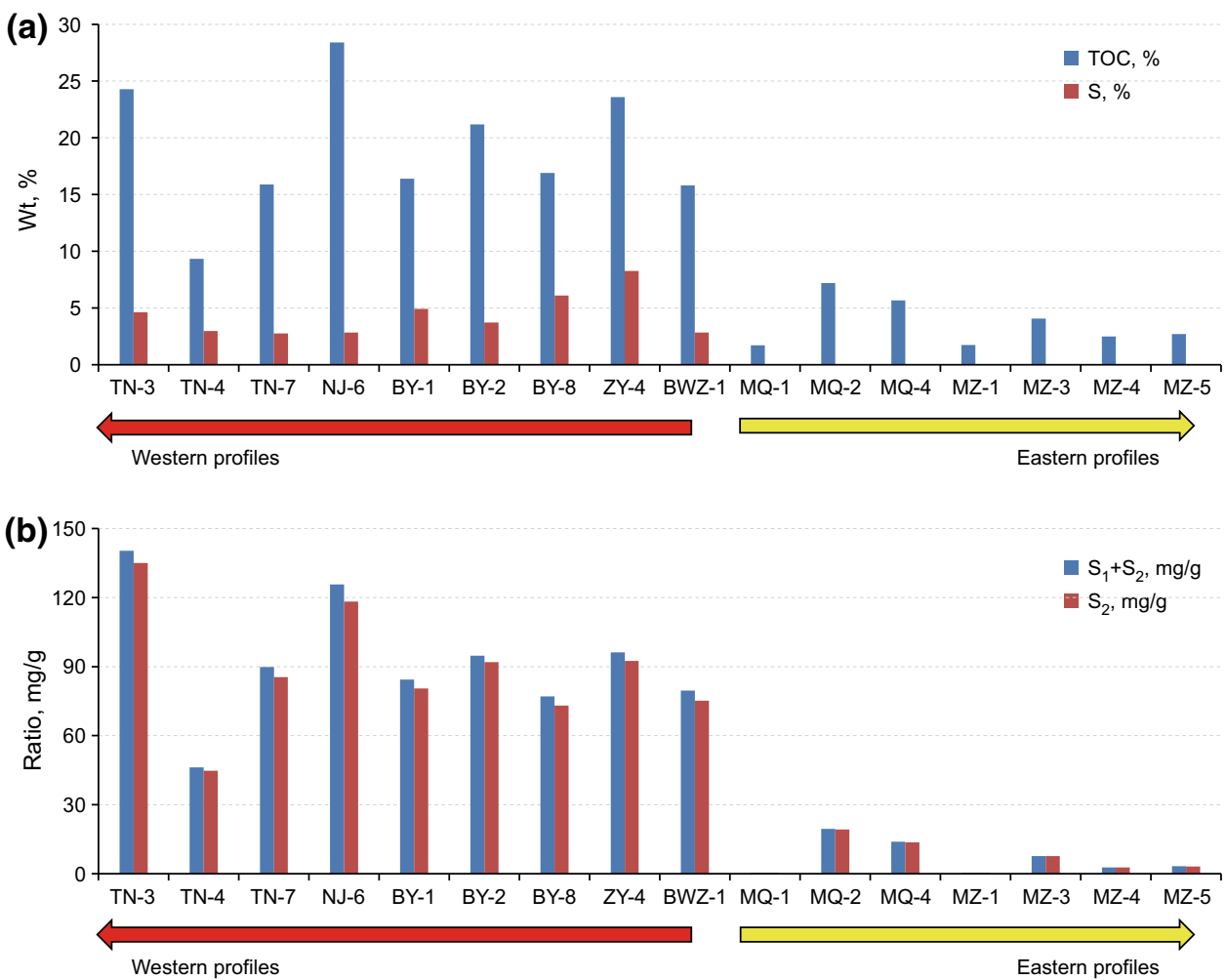
(a)

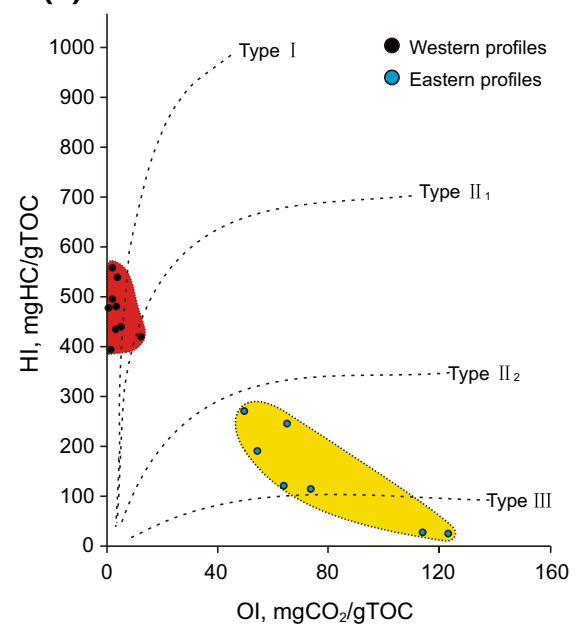

(b)

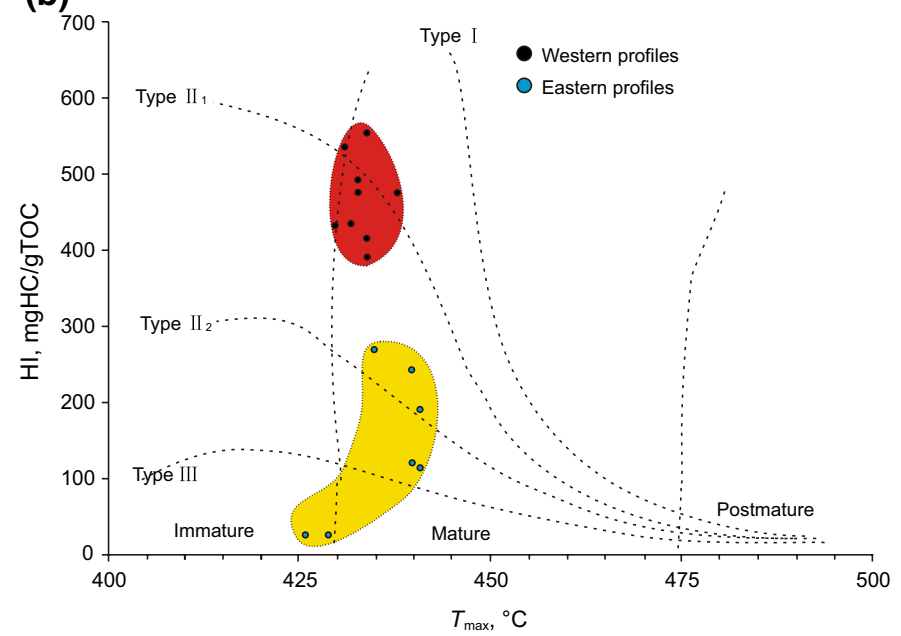

Fig. 5 HI vs. OI cross plot of the shale samples of Yanchang Formation from profiles; Plot of HI vs. Tmax, showing the types of organic matter of shale samples

Fig. 6 Source rock maturity parameters of shale collected in western and eastern profiles. Capital letter in $\mathrm{x}$-coordinate is the abbreviation of profile name, and the munber is the samples number. eg. Zaoyuan (ZY), Niejiahe (NJ), Beiyingou (BY), Yishicun (YCS), Bawangzhuang (BWZ), Tangnihe (TN), Maquan (MQ), and Mazhuangcun (MZ) profiles

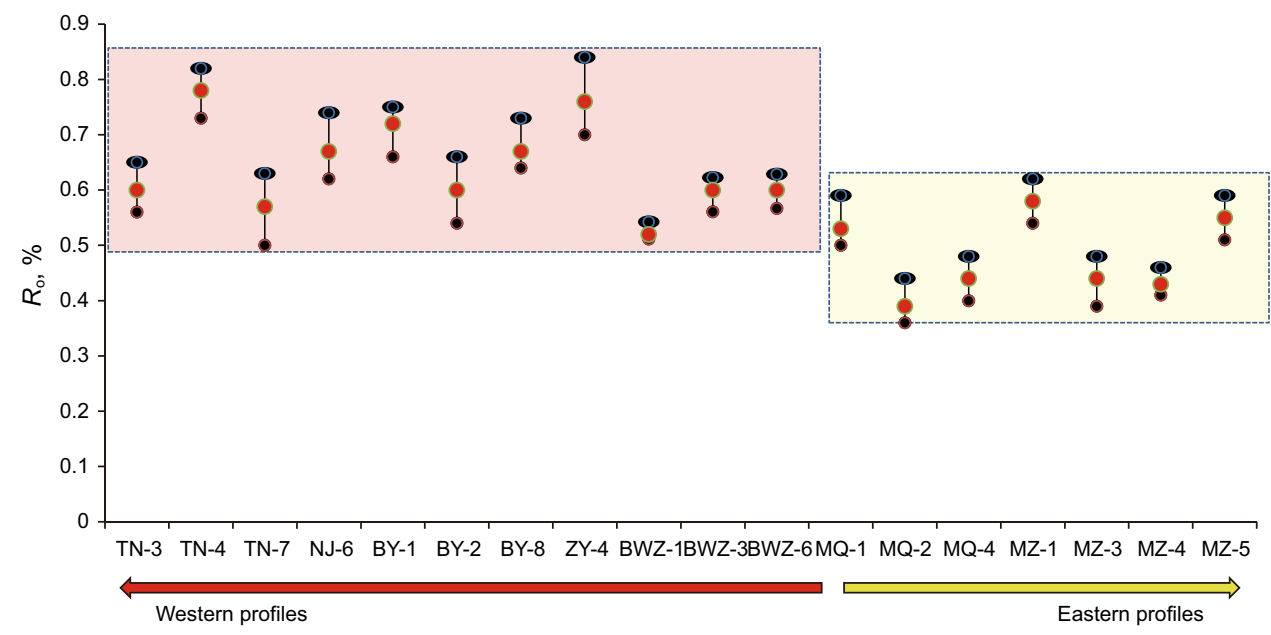

TOC intervals fully coincide with the three sub-members mentioned above (Fig. 8). In Chang $7_{1}$, the layer is thin, and TOC is $2.5 \%-17 \%$; within the high-TOC interval with a thickness of $5 \mathrm{~m}$, Type $\mathrm{II}_{1}$ organic matter is dominant, and the maximum hydrocarbon potential is $26 \mathrm{mg} / \mathrm{g}$; within the remaining part, Type $\mathrm{II}_{2}-\mathrm{III}$ organic matter is dominant, and the maturity is low. In Chang $7_{2}$, TOC is $3.0 \%-18 \%$; within the high-TOC interval with a thickness of $13 \mathrm{~m}$, Type $\mathrm{II}_{1}-\mathrm{II}_{2}$ organic matter is dominant, the maximum hydrocarbon potential is $50 \mathrm{mg} / \mathrm{g}$, and the maturity is low. In Chang $7_{3}$, TOC is $2.5 \%-30 \%$; within the high-TOC interval with a thickness of $5 \mathrm{~m}$, Type $\mathrm{II}_{1}-\mathrm{II}_{2}$ organic matter is dominant, the maximum hydrocarbon potential is $70 \mathrm{mg} / \mathrm{g}$, and the maturity is low; within the remaining part, Type $\mathrm{II}_{1}-\mathrm{III}$ organic matter is dominant. Coincidentally, the study of oil shale in the Binxian area in the south of the Ordos Basin also suggests three sub-member deposits: A1, A2, and A3. Since oil shales in both the southern and southeastern parts of the basin have experienced three development episodes, it can be inferred directly that there should have also been three mineralization episodes in the southern part of the basin.

Based on the geochemical characterization results, together with the shale thickness, hydrocarbon potential, and organic matter type, we suggest that the most favorable shale oil target should be the uppermost Chang $7_{3}$, different from the medium-thick areas determined by Ren. The recovery priority should therefore be F3 $>$ F2 $>$ F1. Overall, the shale in the Tongchuan area is not comparable to that in the USA in view of distribution, thickness, organic matter type, or hydrocarbon potential (Smith 1960; Cashion 1967). As previously estimated, the Tongchuan area has shale oil reserves of 953 million tonnes, technically recoverable shale oil resources of 357 million tons, shale oil resources of 58.8 million tonnes, shale oil in-place of 23.2 million tonnes, and recoverable shale oil resources of 16.6 million tonnes (Li et al. 2014; Ren 2008). It is concluded that selecting the 


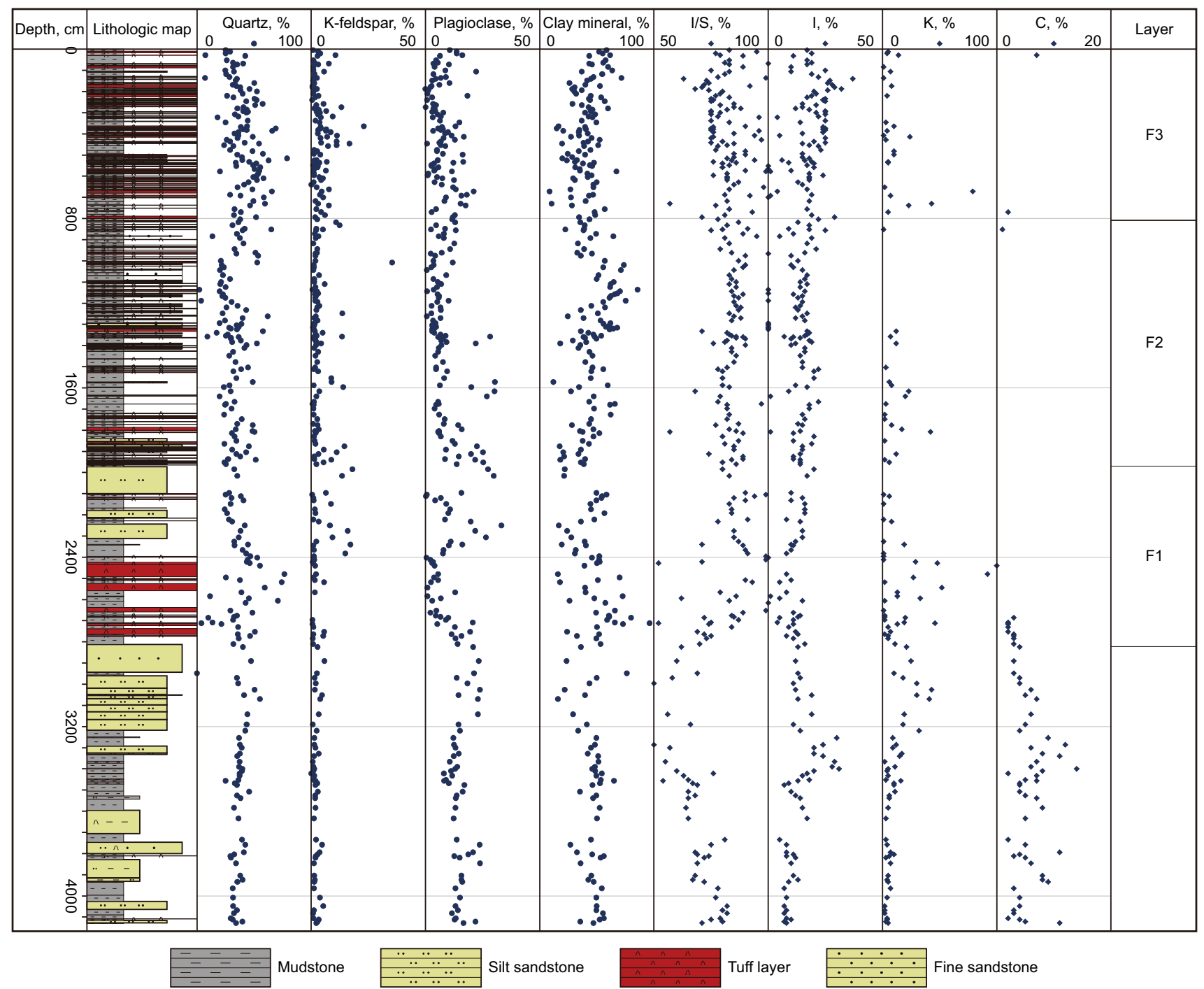

Fig. 7 Mineral composition profile of YSC profiles. According the mineral composition, Mudstone section is divided into three sections. In F1 ,the quartz, clay mineral, and kaoline $(\mathrm{K} \%)$ contents are high, and the albite content is low. In F2, the quartz content is lower,the clay mineral and kaoline contents are low-high- low and form a complete cycle, and the K-feldspar content exhibits some highs. In F3,the quartz, K-feldspar, and kaoline contents are also cyclical

highest-quality horizon through heterogeneity study is critical for shale oil recovery.

\subsection{Sedimentary environment and pattern of the Chang 7 Member organic-rich shale}

The sedimentary environment and pattern of the Chang 7 Member shale in the southeastern part of the Ordos Basin is highly controversial. Some scholars believe that the shale in the Tongchuan area is semideep-deep lacustrine facies (Bai et al. 2009; Yang et al. 2010), while other scholars argue that it comprises shallow lacustrine facies (Bai et al. 2010; Ren 2008). The terms "(shore-) shallow lacustrine facies" and "semideep-deep lacustrine facies" are often confusing, because a lacustrine shore is hardly distinguishable from a shallow lacustrine and a semideep lacustrine is hardly distinguishable from a deep lacustrine. Shallow lacustrine facies can be distinguished from deep lacustrine facies easily; the shoreline is a very important divider, but the shoreline itself is not always easy to define as it is highly variable (Bai et al. 2010). In practice, geologists usually divide oil shale into three types of sedimentary facies, i.e., marine, lacustrine, and marine-continental, and assume marine oil shale to be mainly present in a deep lacustrine environment. Some scholars suggest that this misunderstanding might have been caused by the inclusion of mudstone as oil shale. Bai et al. 


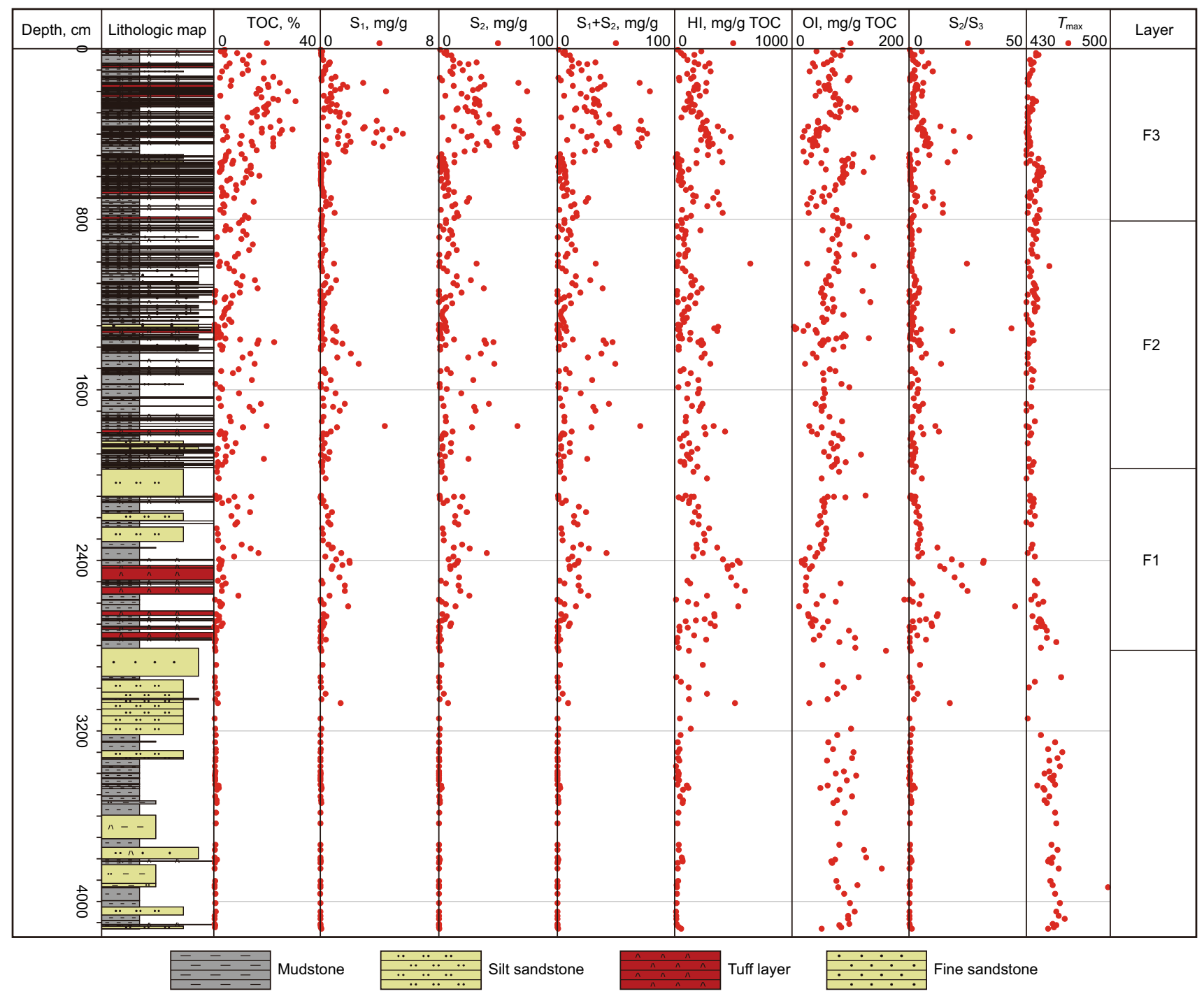

Fig. 8 Organic geochemical profile of YSC profiles. According the oraganic geochemical characteristics, Mudstone section is divided into three sections. In F1, the rock is thin and the TOC ranges between 2.5-17\%. Within the 5-m high-TOC part, the organic type is II1 and the maximum hydrocarbon is $26 \mathrm{mg} / \mathrm{g}$. For the rest, the organic type is II2-III and the maturity level is low. In F2,the TOC ranges between 3.0-18\% and the high-TOC part is $13-\mathrm{m}$ thick. The organic type is II1-II2,the maximum hydrocarbon potential is $50 \mathrm{mg} / \mathrm{g}$, and the maturity level is low. In F3, the TOC ranges between $2.5-30 \%$. Within the 5-m high-TOC part, the organic type is II1-II2 and the rest is II1-III. The maximum hydrocarbon potential is $70 \mathrm{mg} / \mathrm{gand}$ the maturity level is low

(2010) investigated wells with typically different sedimentary facies in the Ordos Basin and concluded that the shallow lacustrine facies corresponded to a limited number of oil shale layers, with small single-layer thickness $(0.5-2.0 \mathrm{~m})$ and small total thickness, shallow-semideep lacustrine facies corresponded to more oil shale layers, with large single-layer thickness $(2-11 \mathrm{~m})$ and large total thickness, and deep lacustrine facies corresponded to multiple oil shale layers, with small single-layer thickness $(0.5-2.0 \mathrm{~m})$ and large total thickness. In this study, the development period and the sedimentary environment and pattern of the Chang 7 Member shale were determined based on the lithology, geochemical characterization results and oil shale formation environment.

According to the lithology of the study area, the eastern sections have fairly thick fine-grained sediments, most of which are silty mudstone. The 7-m-thick mudstone interval is quite low in TOC and has Type III kerogen but no coal. Thus, the eastern sections are considered to contain shore/shallow lacustrine sediments. In contrast, the western sections present significant variation in mudstone thickness, with the concentrated thickness observed in TN, LST, and near BY. In addition to the thick mudstone, the western sections also contain tuff interlayers and fine sandstone 
Fig. 9 Lithologic histogram of the Tongchuan outcrop profiles. The profile name is Zaoyuan (ZY), Niejiahe (NJ), Beiyingou (BY), Yishicun (YCS), Bawangzhuang (BWZ), Tangnihe (TN), Maquan (MQ), and Mazhuangcun (MZ) profiles. Abbreviation name is listed at the top of Lithological columns

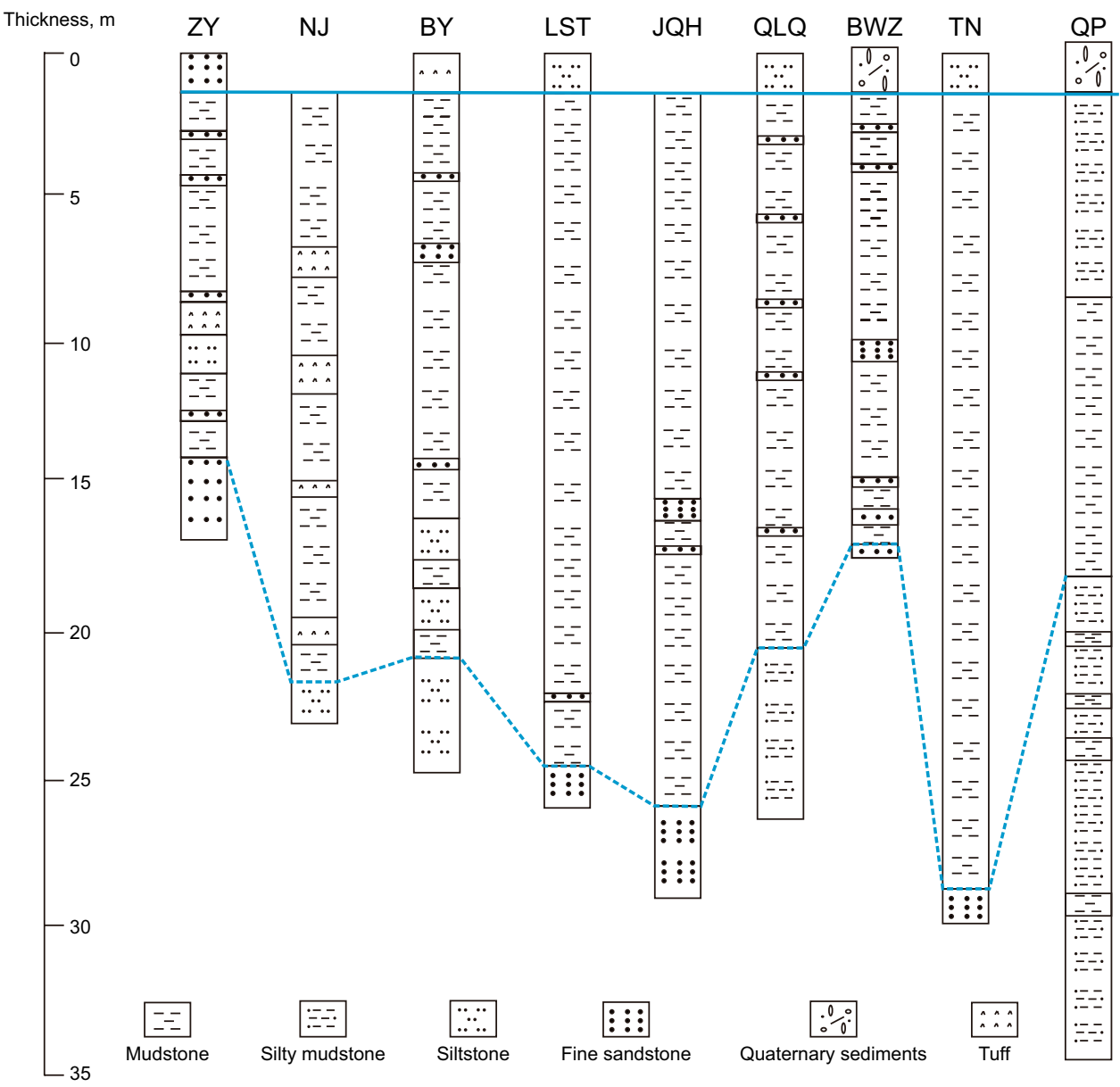

(Figs. 2, 9). Depending on the regional position and the oil shale thickness map, it is believed that the western sections could be shallow/semideep lacustrine facies rather than deep lacustrine facies. Moreover, the geochemical analysis results also confirm that the shale in the Tongchuan area contains Type II-III organic matter, either vertically or horizontally. For both the eastern and western sections, Type III is dominant, but only three shale intervals in the western sections have Type II (Figs. 5, 8). Since the deep lacustrine facies often corresponds to organic-rich shale with high TOC and Type I kerogen, the deltaic semideep lacustrine facies corresponds to mudstone with low TOC and Type II kerogen, and the fluvial and deltaic plain facies corresponds to carbonaceous mudstone with high TOC and Type II-III kerogen, the Chang 2 Member shale in the study area is believed to have been deposited in shallow lacustrine facies, except for the three high-TOC intervals that were deposited in semideep lacustrine facies.

Paleo-climate and paleo-environmental studies indicate that the Chang 7 Member shale in the Tongchuan area was deposited in a platform shallow lacustrine sedimentary environment, where intense regional tectonic movements
(150 layers of tuff) caused three episodes of water deepening in the study area, resulting in a semideep lake environment. Filling of volcanic materials, water deepening, and the consequent changes in the oxidation and reduction environment contributed to a good sedimentary environment (Zimmerle 1985; Frogner et al. 2001). In the Triassic, the climate in the Tongchuan area was warm and humid. Terrestrial plants grew luxuriantly and aquatic organisms were present. These organisms were degraded and preserved under the formation temperature and pressure conditions along with tectonic movements, thus creating an anaerobic environment to allow for the accumulation and deposition of shale-generating original organic matter (Fig. 6). In brief, the paleo-climate constrained the sources of organic matter, the paleo-lake water bodies controlled the deposition and storage conditions of organic matter, the sedimentary facies dominated the type and thickness of the oil shale deposits, and the paleo-structures determined the organic enrichment through volcanic and turbidity current events and controlled the elevation and exposure of oil shale in the study area. Combining the tectonic setting, organic matter type, climate, and sedimentary characteristics, we established the 

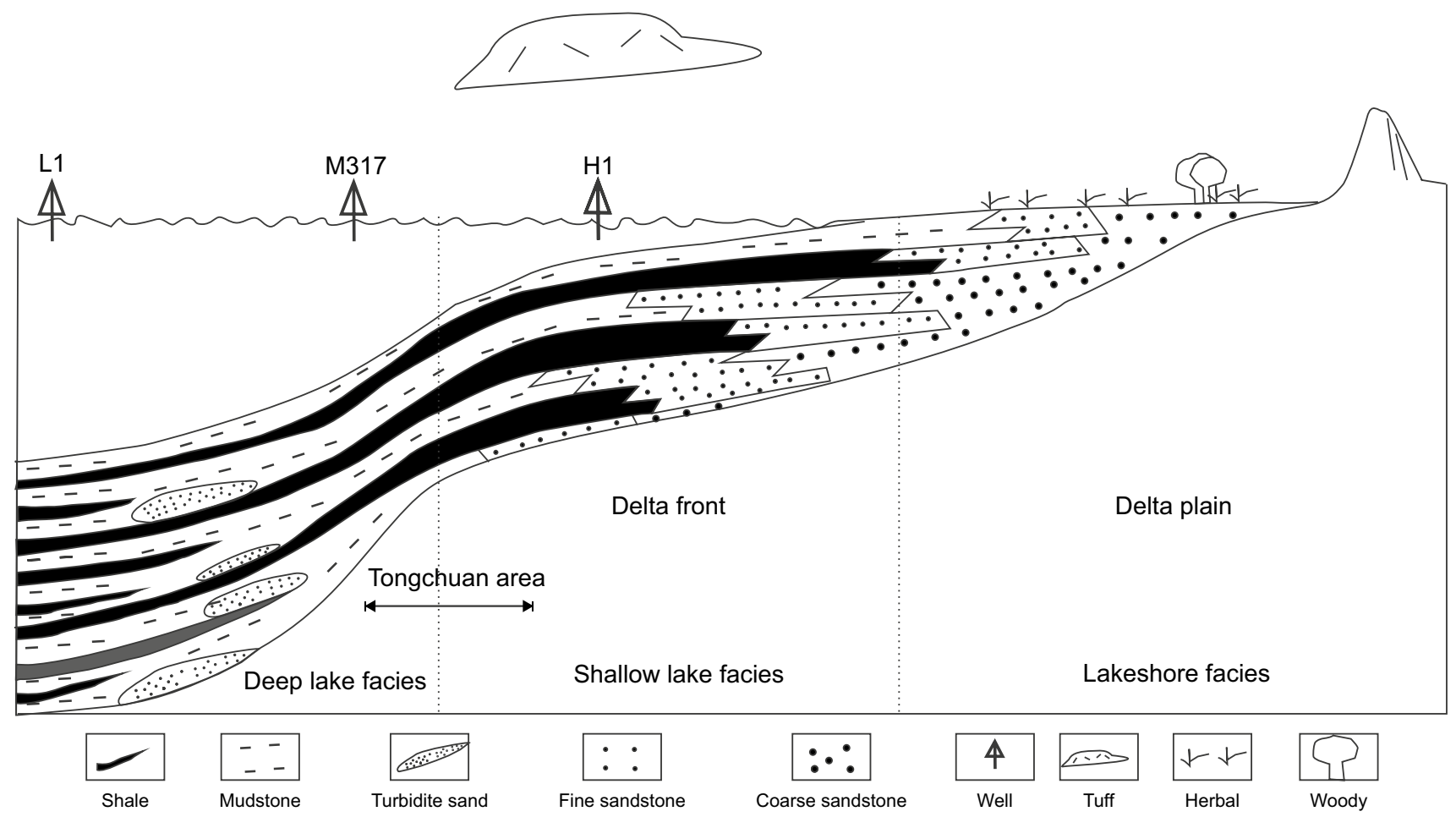

Fig. 10 Sedimentary pattern of Chang7 shale developed in the Ordos basin, base map is modified from (Bai et al., 2010)

sedimentary pattern of the Chang 7 Member shale in the southeastern Ordos Basin, as shown in Fig. 10.

\section{Conclusions}

In this study, eight outcrop sections in the Tongchuan area were observed and sampled to investigate the Chang $7 \mathrm{Mem}$ ber, and sedimentary and geochemical characterizations were conducted for the well-outcropped YSC section. The study results show that the Chang 7 Member shale is widely distributed laterally with variable thickness. The organicrich interval is 7-25 m thick in total and exhibits obvious horizontal variation in mineral composition. In the eastern sections, the shale contains organic matter of Type $\mathrm{II}_{2}-\mathrm{III}$ and is low in thermal maturity, with high clay mineral content, low K-feldspar content, and no pyrite. In the western sections, the shale contains Type $\mathrm{II}_{1}$ organic matter and is low in thermal maturity, with high clay mineral, K-feldspar, and pyrite contents. Apparently, the immature shale in the eastern sections implies no shale oil is available for recovery. In contrast, the shale in the western sections has high hydrocarbon potential and is thus a potential for shale oil recovery.

We collected samples from 156 layers of tuffs from the YSC section at a centimeter-scale. The results of mineral composition and geochemical study suggest that the shale presents three obvious intervals in mineral composition and organic abundance vertically. Based on the TOC and hydrocarbon potential evaluation, we conclude that the recovery priority should be F3 $>$ F2 $>$ F1. Given the high heterogeneity of the oil shale in the Tongchuan area, selecting the highest-quality horizon through heterogeneity study is critical for shale oil recovery.

Depending on the regional position and the oil shale thickness map, it is believed that the western sections should be shallow/semideep lacustrine facies rather than deep lacustrine facies. The shale intervals in the eastern and western sections are generally shallow lacustrine facies, but only three shale intervals in the western sections reflect semideep lacustrine facies. It is concluded that the paleo-climate constrained the sources of organic matter, the paleo-lake water bodies controlled the deposition and storage conditions of organic matter, the sedimentary facies determined the type and thickness of the oil shale deposits, and the paleo-structures dominated the organic enrichment through volcanic and turbidity current events and controlled the elevation and exposure of oil shale in the study area.

Acknowledgements This study was supported by the National Basic Research Program of China (973 Program, No. 2014CB239001). We are deeply grateful for Li C.C. of Geological Survey Center, Shanxi Province, for his help in the field survey and outcrop.

Open Access This article is distributed under the terms of the Creative Commons Attribution 4.0 International License (http://creativeco 
mmons.org/licenses/by/4.0/), which permits unrestricted use, distribution, and reproduction in any medium, provided you give appropriate credit to the original author(s) and the source, provide a link to the Creative Commons license, and indicate if changes were made.

\section{References}

Bai YL, Ma L, Wu WJ, Ma YH. Geological characteristics and resource potential of oil shale in Ordos Basin. Geol China. 2009;36(5):1123-37 (in Chinese).

Bai WH, Wu YB, Gao ZL, Sun SS. Study on the mechanism of oil shale minerogenetic enrichment in the arm of shallow to half-deep lake depositional environment. Geol Surv Res. 2010;33(3):207-14 (in Chinese).

Cashion WB. Geology and fuel resources of the Green River Formation, Southeastern Uinta Basin, Utah and Colorado. US, Geological Survey professional paper 548, 1967. https://doi.org/10.3133/ pp548.

Clarkson CR, Nobakht M, Kaviani D. Production analysis of tightgas and shale-gas reservoirs using the dynamic-slippage concept. SPE J. 2012;17(01):230-42. https://doi.org/10.2118/14431 7-PA.

Cui JW, Zhu RK, Li SX, Yang Z, Zhang ZY. Movable oil and its controlling factors in tight sandstone. Pet Geol Exp. 2016;38(4):53642. https://doi.org/10.11781/sysydz201604536 (in Chinese).

Deng XQ, Lin XF, Liu XY, Pang JL, Lu JW, Li SX, Liu X. Discussion on relationship between sedimentary evolution of Triassic Yanchang Formation and the early Indosinian movement in Ordos Basin. J Palaeogeogr. 2008;10(2):159-66 (in Chinese).

Deng XQ, Liu XS, Li SX. The relationship between compacting history and hydrocarbon accumulating history of the super-low permeability reservoirs in the Triassic Yanchang Formation in the Ordos Basin. Oil Gas Geol. 2009;30(2):156-61 (in Chinese).

Donovan AD, Staerker TS, Pramudito A, Li WG, Gorbett MJ, Lowery CM, Romero AM, Gardner RD. The Eagle Ford outcrops of West Texas: a laboratory for understanding heterogeneities within unconventional mudstone reservoirs. GCAGS J. 2012;1:162-85.

Frogner P, Gíslason SR, Óskarsson N. Fertilizing potential of volcanic ash in ocean surface water. Geology. 2001;29(6):487-90. https://doi.org/10.1130/0091-7613(2001)029\%3c0487:FPOVA I\%3e2.0.CO;2.

Huang SJ, Huang KK, Feng WL, Tong HP, Liu LH, Zhang XH. Mass exchanges among feldspar, kaolinite and illite and their influences on secondary porosity formation in clastic diagenesis-A case study on the Upper Paleozoic, Ordos Basin and Xujiahe Formation, Western Sichuan depression. Geochimica. 2009;38(5):498-506 (in Chinese). https://doi.org/10.19700 /j.0379-1726.2009.05.009.

Jarvie DM (2012) Shale resource systems for oil and gas: part 2 shale-oil resource systems. In: Breyer JA, editor. Shale reservoir-Giant resources for the 21st century. AAPG Memoir 97; 2012. p. 89-119. https://doi.org/10.1306/13321447m973489.

Lazar OR, Bohacs KM, Macquaker JH, Schieber J, Demko TM. Capturing key attributes of fine-grained sedimentary rocks in outcrops, cores, and thin sections: nomenclature and description guidelines. J Sediment Res. 2015;85(3):230-46. https://doi. org/10.2110/jsr.2015.11.

Lu JC, Li YH, Wei XY, Wei JS. Research on the depositional environment and resources potential of the oil shale in the Chang7 Member, Triassic Yanchang Formation in the Ordos Basin. J Jilin Univ (Earth Sci Ed). 2006;36(6):928-32 (in Chinese). https://doi. org/10.13278/j.cnki.jjuese.2006.06.010.
Li YH, Jiang T, Wu FL, Zhang HY, Yao ZG, Wang BW. Evaluation methods and results of oil shale resources in southeastern Ordos Basin. Geol Bull China. 2014;33(9):1417-24 (in Chinese).

Li YH, Li JC, Jiang T, Wei JS, Lu JC, Hang J. Characteristics of the Triassic oil shale in the Hejiafang area, Ordos Basin. J Jilin Univ (Earth Sci Ed). 2009;39(1):65-71 (in Chinese).

Miller BA, Paneitz JM, Yakeley S, Evans KA. Unlocking tight oil: Selective multistage fracturing in the Bakken Shale. In: SPE annual technical conference and exhibition. 2008. https://doi. org/10.2118/116105-ms.

Ren LJ. Characteristics and resource evaluation of the Mesozoic oil shales in Binxian-Tongchuan, Ordos Basin. Masters Dissertation, Jilin University, 2008 (in Chinese).

Schieber J, Southard J, Thaisen K. Accretion of mudstone beds from migrating floccule ripples. Science. 2007;318(5857):1760-3. https ://doi.org/10.1126/science.1147001.

Smith JW. Ultimate composition of organic material in Green River oil shale. Bureau of Mines, Laramie, Wyo. (USA). Petroleum Research Center. 1960.

Sonnenberg SA, Vickery J, Theloy C, Sarg JF. Middle Bakken facies, Williston basin, USA: a key to prolific production. AAPG Annual Convention and Exhibition, Huston, USA. 2011.

Sruoga P, Rubinstein N, Hinterwimmer G. Porosity and permeability in volcanic rocks: a case study on the Serie Tobiffera, South Patagonia, Argentina. J Volcanol Geoth Res. 2004;132(1):31-43. https ://doi.org/10.1016/S0377-0273(03)00419-0.

Wang DY, Xin BS, Yang H. Zircon SHRIMP U-Pb age and geological implication of tuff at the bottom of Chang-7 member of Yanchang Formation in the Ordos Basin. Sci China Earth Sci. 2014;44(10):2160-71. https://doi.org/10.1007/s1143 0-014-4979-0.

Yang Y, Li W, Ma L. Tectonic and stratigraphic controls of hydrocarbon systems in the Ordos Basin: a multicycle cratonic basin in central China. AAPG Bull. 2005;89(2):255-69. https://doi. org/10.1306/10070404027.

Yang Z, Hou LH, Tao SZ, Cui JW, Wu ST, Lin SH, Pan SQ. Formation conditions and "sweet spot" evaluation of tight oil and shale oil. Pet Explor Dev. 2015;42(5):609-20. https://doi.org/10.11698 /PED.2015.05.02.

Yang H, Zhang WZ, Peng PA, Liu F, Luo LR. Oil detailed classification and oil-source correlation of Mesozoic lacustrine oil in Ordos Basin. J Earth Sci Environ. 2016;38(2):196-205 (in Chinese).

Yang H, Li SX, Liu XY. Characteristics and resource prospects of tight oil and shale oil in Ordos Basin. Acta Pet Sin. 2013;34(1):1-11. https://doi.org/10.7623/syxb201301001.

Yang H, Dou WT, Liu XY, Zhang CL. Analysis on sedimentary facies of Member 7 in Yanchang Formation of Triassic in Ordos Basin. Acta Sedimentol Sin. 2010;28(2):254-63 (in Chinese).

Zimmerle W. New aspects on the formation of hydrocarbon source rocks. Geol Rundsch. 1985;74(2):385-416. https://doi. org/10.1007/BF01824905.

Zou CN, Yang Z, Cui JW, Zhu RK, Hou LH, Tao SZ, Yuan XJ, Wu ST, Lin SH, Wang L, Bin B, Yao JL. Formation mechanism, geological characteristics and development strategy of nonmarine shale oil in China. Pet Explor Dev. 2013;40(1):15-27.

Zou CN, Zhang XY, Luo P, Wang L, Luo Z, Liu LH. Shallow-lacustrine sand-rich deltaic depositional cycles and sequence stratigraphy of the Upper Triassic Yanchang Formation, Ordos Basin, China. Basin Res. 2010;22(1):108-25. https://doi.org/10.111 $1 / \mathrm{j} .1365-2117.2009 .00450 . x$.

Zhang WZ, Yang H, Peng PG. Influence of volcanism on development of Chang7 hydrocarbon source rock. Geochimica. 2009;38(6):573-82 (in Chinese). https://doi.org/10.19700 /j.0379-1726.2009.06.007. 
Zhang WZ, Li SP, Xu ZQ. Analysis of industrial utilization prospect of Upper Triassic Chang-7 oil shale in Ordos Basin. Low Permeability Oil Gas Field. 2006;11(1):13-7 (in Chinese).

Zhang WZ, Yang H, Yang WW, Wu K, Liu F. Assessment of geological characteristics of lacustrine shale oil reservoir in Chang7 member of Yanchang Formation, Ordos Basin. Geochimica. 2015;44(5):505-15 (in Chinese). https://doi.org/10.19700 /j.0379-1726.2015.05.010.
Zhang W, Yang H, Xie L, Yang Y. Lake-bottom hydrothermal activities and their influence on high-quality source rock development: A case from Chang 7 source rocks in Ordos Basin. Petrol Explor Dev. 2010;37(4):424-429.

Zhang WZ, Li JF. Oil and gas source of Ordos Basin. China Pet Explor. 2001;6(4):28-36 (in Chinese). 